\title{
The Effects Of Increased Transportation Cost On The Interregional Flows Of Selected Fresh Produce In Late Spring
}

\author{
H. L. Tyan and J. E. Epperson*
}

Economic development in the U.S. has been associated with dramatically improved means of transportation, resulting in a vastly lower cost of shipping with faster and more dependable delivery. In turn, such improvements in the transportation system have served greater geographic specialization yielding less self sufficiency in many areas of the country.

With the advent of OPEC (Organization of Petroleum Exporting Countries) transportation costs began to rise as a result of higher energy prices. Real energy costs increased about 184 percent from 1973 to mid 1981, while the average real increase each year has been approximately 15 percent (Survey of Current Business).

The outlook for the foreseeable future does not show a return to cheap energy. Moreover, as Tyner indicates, we are in another energy transition period, moving from petroleum fuels to alternative energy sources.

With higher energy costs the stage appears set for a reversal of geographic specialization of agricultural production, blurring comparative and absolute advantage.

A review of the literature reveals that there has not been a great deal accomplished concerning this subject. Recent work, by Bauer, et al. in 1981, measured the effect of an increase in energy costs on the trade flow of fresh peaches in the U.S. by reactive programming. The works of Clevenger and Geithman, Babb, and Mathia and Brooker examined the competitive position of spatially separated fresh markets but did not examine the impact of changing energy costs. Adams, et al. in 1977 examined the effects of energy cost increases on agricultural production in California, but did not address the impact of rising transportation cost.

The hypothesis of this paper is that as transportation cost increases, the traditional fresh fruit and vegetable production areas, i.e. Florida and California, will ship more produce to local markets and less to the large population centers of the Northeast and Midwest. Thus, Georgia, ${ }^{1}$ which has not been a dominant supplier, may become more important as an origin of fresh fruits and vegetables. The hypothesis is "tested" by compar-

*Research Coordinator, and Associate Professor, respectively, Agricultural Economics Department, Georgia Station, University of Georgia. 
ing a base model and an adjusted model. This comparison measures the impact of increased transportation costs on spatial prices, the distribution of selected fresh produce, and the change in supply patterns in South Georgia.

The analysis employs a spatial equilibrium model which encompasses 13 U. S. produce markets or regions. Activity analysis involving a measure of risk is contained in the Georgia region. The model is couched in a quadratic programming framework as it involves multiproducts, multiregions, and linear demand functions. Representative produce commodities pertinent to this study include: watermelons, tomatoes, green peppers, cucumbers, and sweet corn. The commodities were selected because of indicated growth potential as reflected in per capita consumption and population statistics (Food Consumption, Prices, and Expenditures), Table 1. ${ }^{2}$

Included in the analysis were other commodities which compete directly with selected produce crops for land. They are soybeans, field corn, and peanuts. The relevant national market window for Georgia and competing regions common to the selected produce crops occurs in late spring (June) as shown from AMS, USDA Unloads.

\section{TABLE 1.}

U.S. Resident Population and Per Capita Consumption of Selected Produce Items by Year

\begin{tabular}{lcccccr}
\hline Years & Population & Watermelons & Tomatoes & $\begin{array}{c}\text { Green } \\
\text { Peppers }\end{array}$ & Cucumbers & $\begin{array}{r}\text { Sweet } \\
\text { Corn }\end{array}$ \\
\hline & (millions) & & \multicolumn{5}{c}{ (pounds) } \\
1960 & 180.0 & 17.2 & 12.6 & 2.4 & 2.9 & 8.5 \\
1961 & 183.0 & 16.3 & 12.6 & 2.5 & 3.0 & 8.4 \\
1962 & 185.8 & 14.6 & 12.7 & 2.3 & 2.8 & 8.3 \\
1963 & 188.5 & 15.9 & 12.0 & 2.5 & 3.1 & 8.2 \\
1964 & 191.1 & 14.8 & 12.2 & 2.3 & 3.0 & 7.8 \\
1965 & 193.5 & 15.7 & 12.0 & 2.3 & 3.1 & 8.1 \\
1966 & 195.6 & 14.8 & 12.4 & 2.4 & 3.0 & 7.4 \\
1967 & 197.5 & 14.2 & 12.4 & 2.6 & 3.1 & 8.0 \\
1968 & 199.4 & 14.4 & 11.9 & 2.8 & 2.9 & 7.8 \\
1969 & 201.4 & 13.7 & 11.7 & 2.6 & 3.1 & 7.2 \\
1970 & 204.0 & 14.4 & 12.3 & 2.4 & 3.2 & 7.9 \\
1971 & 206.8 & 14.1 & 11.4 & 2.5 & 3.1 & 7.5 \\
1972 & 209.3 & 13.2 & 12.2 & 2.7 & 3.3 & 7.9 \\
1973 & 211.4 & 13.8 & 12.6 & 2.8 & 3.0 & 8.0 \\
1974 & 213.3 & 11.9 & 12.0 & 3.0 & 3.4 & 7.7 \\
1975 & 215.5 & 12.2 & 12.1 & 3.1 & 3.2 & 7.9 \\
1976 & 217.6 & 13.5 & 12.7 & 3.3 & 3.7 & 8.2 \\
1977 & 219.8 & 13.5 & 12.5 & 3.4 & 4.0 & 7.6 \\
\hline
\end{tabular}

Source: Food Consumption, Prices, and Expenditures, USDA, 1978. 


\section{THE PROGRAMMING MODEL}

The basic quadratic programming model used in this study is derived from the work of Takayama and Judge. An adaptation of the model in matrix notation which maximizes net social payoff follows:

(1) OBJ: $\operatorname{Max} \operatorname{NSP}(Y, X)=$

$$
\begin{gathered}
{\left[\theta^{\prime}, \mathrm{T}^{\prime \prime}\right]\left[\begin{array}{l}
\mathrm{Y} \\
\mathrm{X}
\end{array}\right]-1 / 2\left[\mathrm{Y}^{\prime} \mathrm{X}^{\prime}\right]\left[\begin{array}{ll}
\Sigma & 0 \\
0 & 0
\end{array}\right]\left[\begin{array}{l}
\mathrm{Y} \\
\mathrm{X}
\end{array}\right]} \\
\text { (2) s.t. }\left[\begin{array}{rr}
\mathrm{I} & -\mathrm{G} \\
\mathrm{A} \\
\mathrm{C}^{\prime}
\end{array}\right] \quad\left[\begin{array}{l}
\mathrm{Y} \\
\mathrm{X}
\end{array}\right] \leqslant\left[\begin{array}{l}
0 \\
\mathrm{~S}^{*} \\
\mathrm{~S}
\end{array}\right]
\end{gathered}
$$

and

$$
\left(\mathrm{Y}^{\prime} \mathrm{X}^{\prime}\right) \geqslant \mathrm{O}^{\prime}
$$

where

$$
\begin{aligned}
\text { NSP }= & \text { Net Social Payoff } \\
\mathrm{Y}= & \text { a vector of aggregate demand activity levels in } 100 \mathrm{cwt} . \\
\mathrm{X}= & \text { a vector of interregional activity levels in } 100 \mathrm{cwt} . \\
\theta= & \text { a vector of intercepts of price dependent demand } \\
& \text { equations. } \\
\mathrm{T}= & \text { a vector of costs per } 100 \mathrm{cwt} \text {, including variable and risk } \\
& \text { costs of production and transportation costs. } \\
\Sigma= & \text { a nonnegative diagonal submatrix of demand coefficients, } \\
& \text { implying no cross price flexibilities. } \\
\mathrm{I}= & \text { an identity submatrix. } \\
\mathrm{G}= & \text { a submatrix including elements of } 1 \text { and } 0 . \\
\mathrm{A}^{*}= & \text { a submatrix including elements of } 1 \text { and } 0 . \\
\mathrm{C}= & \text { a vector of technical coefficients in acres per } 100 \mathrm{cwt} . \\
\mathrm{S}^{*}= & \text { a vector of fixed supplies in } 100 \mathrm{cwt} \text { for all regions, except } \\
& \text { Georgia, and the peanut constraint in } 100 \mathrm{cwt} \text { for Georgia. } \\
\mathrm{S}= & \text { the availability of land (immobile primary commodity) in } \\
& \text { South Georgia in acres. }
\end{aligned}
$$

The model maximizes the area under the demand functions minus all costs subject to the constraint set. The constraints incorporated in the model are of the following meaning and form:

a) The quantity actually consumed, say $Y$, is less than or equal to the quantity shipped from all supply regions including the region of destination. Thus,

$$
\text { IY }-\mathrm{GX} \leqslant \mathrm{O}
$$

b) Fixed supplies, $\mathrm{S}^{*}$ in this analysis, are greater than or equal to supplies shipped. Thus, 


$$
A^{*} \mathrm{X} \leqslant \mathrm{S}^{*}
$$

c) Immobile primary commodity allocation constraint:

$$
\mathrm{C}^{\prime} \mathrm{X} \leqslant \mathrm{S} \text {, and }
$$

d) Nonnegative constraint:

$$
\left(\mathrm{Y}^{\prime} \mathrm{X}^{\prime}\right) \geqslant \mathrm{O}^{\prime}
$$

\section{MODEL COMPONENTS}

\section{Demand}

OLS was used to estimate demand functions for selected fresh produce items. The general form of the relationship for a given commodity is (8) $\quad \mathrm{P}=\mathrm{f}(\mathrm{Q}, \mathrm{I}, D)$

where $P$ is price per hundred cwt, $Q$ is quantity in hundred cwt, I is income per capita, and $D$ is a vector of dummy variables. Dummy variables were added to equation 8 to allow prices to vary by consuming center, month, and year (intercept shifters); to allow the relationship between $P$ and $Q$ to vary by consuming center and month; and to allow the relationship between $P$ and $I$ to vary by market (slope shifters). All coefficients in the final equations were significant at the 90 percent level or above; most were significant at the 99 percent level. The $\mathbf{R}^{2}$ for each estimated demand equation is: 0.78 for watermelons, 0.57 for tomatoes, 0.77 for green peppers, 0.67 for cucumbers, and 0.74 for sweet corn. Derived demand functions used in the quadratic programming model are given in Table 2 by market and commodity.

Some of the market designations shown in I Iable 2 encompass more than one market. Cleveland and Cincinnati are combined and labeled Cleveland while Detroit and Minneapolis are joined and designated Detroit. The market area represented as New York includes Baltimore, Boston, New York, Philadelphia, and Pittsburgh. ${ }^{4}$ St. Louis includes both Kansas City and St. Louis.

Data used to estimate demand functions for commodities and markets are from the AMS-USDA and the Department of Commerce for June through September from 1972 through 1975 and June through August in 1976. The same quantity data after this period are not available. Total quantities received in each market regardless of origin were used in estimating demand relations.

Demand functions for field corn and soybeans were estimated for Georgia using OLS. Data for 1963-77 from Agricultural Statistics and Survey of Current Business were used to estimate relationships of the following form:

$$
P=f(Q, S, C, I)
$$

where $P$ is deflated price per hundred cwt, $Q$ is quantit in hundred cwt, $S$ is stock at the end of the year, C represents qua'tity in hundred cwt of the 
TABLE 2

Price Dependent Demand Functions for Selected Produce Items in Thirteen Markets, June 1975

\begin{tabular}{|c|c|c|c|c|c|c|c|c|c|c|}
\hline \multirow[b]{2}{*}{ Markets } & \multicolumn{2}{|c|}{ Watermelons } & \multicolumn{2}{|c|}{ Tomatoes } & \multicolumn{2}{|c|}{ Green Peppers } & \multicolumn{2}{|c|}{ Cucumbers } & \multicolumn{2}{|c|}{ Sweet Corn } \\
\hline & Intercept & Slope & Intercept & Slope & Intercept & Slope & Intercept & Slope & Intercept & Slope \\
\hline Atlanta & 618.84 & -0.0123 & $4,320.54$ & -0.5046 & $2,958.94$ & -1.1196 & $1,902.16$ & -0.1898 & $1,453.20$ & -0.2649 \\
\hline Birmingham & 572.39 & -0.0123 & $4,254.83$ & -0.5046 & $2,865.81$ & -1.1196 & $1,870.64$ & -0.1898 & $1,460.91$ & -0.2649 \\
\hline Chicago & $1,172.93$ & -0.1314 & $4,714.26$ & -0.5046 & $3,516.91$ & -1.1196 & $2,091.00$ & -0.1898 & $1,406.08$ & -0.0578 \\
\hline Cleveland & 770.69 & -0.0057 & $4,085.20$ & -0.2172 & $3,268.16$ & -0.5773 & $2,251.52$ & -0.8793 & $1,546.48$ & -0.1242 \\
\hline Columbia & 556.56 & -0.0123 & $4,317.96$ & -0.5046 & $2,955.28$ & -0.1196 & $1,547.37$ & -0.1898 & $1,454.92$ & -0.2649 \\
\hline Dallas & 615.80 & -0.0123 & $4,454.23$ & -1.7785 & $3,430.35$ & -1.1196 & $1,966.28$ & -0.1898 & $1,799.51$ & -1.7610 \\
\hline Detroit & 860.82 & -0.0060 & $4,832.44$ & -0.0235 & $3,677.52$ & -1.4065 & $2,018.03$ & -0.0762 & $1,587.22$ & -0.1188 \\
\hline Los Angeles & 892.50 & -0.0123 & $4,707.64$ & -0.5046 & $5,520.68$ & -4.5928 & $1,478.47$ & -0.1898 & $1,687.94$ & -0.2649 \\
\hline Louisville & 673.39 & -0.0123 & $3,803.06$ & -0.5046 & $3,068.69$ & -1.1196 & $1,939.30$ & -0.1898 & $1,855.94$ & -2.9377 \\
\hline Miami & 765.46 & -0.0123 & $4,527.94$ & -0.5046 & $3,252.87$ & -1.1196 & $2,001.64$ & -0.1898 & $1,406.50$ & -0.2649 \\
\hline New Orleans & 678.26 & -0.0123 & $4,224.89$ & -0.5046 & $3,142.62$ & -1.1196 & $1,856.28$ & -0.1898 & $1,467.37$ & -0.2649 \\
\hline New York & 822.66 & -0.0023 & $4,536.10$ & -0.0685 & $3,311.46$ & -0.3075 & $1,972.71$ & -0.0332 & $1,471.92$ & -0.0452 \\
\hline St. Louis & 836.84 & -0.0055 & $4,581.96$ & -0.2116 & $3,940.62$ & -7.0472 & $2,033.21$ & -0.0858 & $1,347.54$ & -0.1053 \\
\hline
\end{tabular}


competing crop, and I is deflated per capita income. The $\mathrm{R}^{2}$ is 0.59 for the field corn demand relation while it is 0.63 for the soybean relation. Test results for autocorrelation were inconclusive, and multicollinearity problems were not detected. So as to conform to the structural requirements of the quadratic model, S, C, and I were incorporated into the intercepts of the demand functions for field corn and soybeans.

The derived demand function for field corn for use in the quadratic programming model is

$$
\mathrm{P}=538.41-0.000084 \mathrm{Q}
$$

and for soybeans the function is

$$
\mathrm{P}=1163.75-0.002556 \mathrm{Q} \text {. }
$$

The quantity coefficient for field corn was significant only at the 50 percent level yet it did have the correct sign while the quantity coefficient for soybeans was significant at the 99 percent level.

Supply

Supplies of selected fresh produce were fixed for all regions except Georgia where produce and row crops were allowed to compete for suitable land. Table 3 shows supplies by region designation and commodity as

\section{TABLE 3}

Fixed Supplies of Selected Produce Items for Thirteen Regions in June, 1975

\begin{tabular}{lrrrrr}
\hline & \multicolumn{5}{c}{$\begin{array}{c}\text { Commodities } \\
\text { Green } \\
\text { Region }\end{array}$} \\
& Watermelons & Tomatoes & Peppers & Cucumbers & Corn \\
\hline & & & $(100 \mathrm{cwt})$ \\
Atlanta $^{\mathrm{b}}$ & $1,161.00$ & 332.00 & 161.30 & 157.80 & 141.60 \\
Birmingham $_{\text {Chicago }}$ & 112.50 & 180.00 & 5.12 & 30.80 & 105.27 \\
Cleveland & 0.00 & 12.00 & 0.00 & 13.47 & 5.44 \\
Columbia & 0.00 & 336.00 & 0.00 & 36.57 & 1.81 \\
Dallas & 265.50 & $2,744.00$ & 358.40 & $2,340.80$ & 152.46 \\
Detroit & $4,027.50$ & 354.00 & 364.80 & 186.73 & 79.86 \\
Los Angeles & 0.00 & 4.00 & 0.00 & 0.00 & 0.00 \\
Louisville & 629.00 & $1,392.00$ & 189.44 & 654.50 & 943.80 \\
Miami & 0.00 & 46.00 & 5.12 & 13.48 & 0.00 \\
New Orleans & $15,601.50$ & $1,492.00$ & $1,041.92$ & $1,027.95$ & $5,386.92$ \\
New York & 22.50 & 124.00 & 409.60 & 165.55 & 21.78 \\
St. Louis & 0.00 & 368.00 & 7.68 & 292.60 & 5.44 \\
\hline
\end{tabular}

Cities listed represent regions of origin which in most cases encompass several states (see Table 4).

bFixed supplies were not imposed on the model for the Atlanta region; however, these were actual supplies originating in Georgia in the base period of analysis, June 1975. 
derived from unload data for the base period of the model. Table 4 reflects origin areas and associated origin points which are synonymous with market designations. These points are used to represent shipping destinations and origins.

The distribution of supplies from origins not included in Table 4 are not considered in this analysis. For example, almost 43 percent of the tomatoes received in Detroit in June 1975 originated in Mexico (USDA, AMS). Shipments from Mexico are not reflected in the shipping pattern results of this paper. Similarly, actual supplies from the U.S. to Canada were subtracted from total supplies of U.S. origin.

A few states are assigned to more than one origin point due to spatial propinquity, e.g. Ohio is represented by both New York City and Cleveland, thus supplies from Ohio are split between these two origin points (Table 4).

\section{Constraints}

An estimate of suitable cropland in South Georgia of 3,396,034 acres was obtained from the Census. Table 5 shows land constraint coefficients in acres per $100 \mathrm{cwt}$ for crops considered in the model. In addition, information used in the derivation of land constraint coefficients is presented in Table 5. Peanut production in Georgia was limited to 172,618 hundred cwt which corresponds to the peanut allotment restriction imposed in 1975 .

TABLE 4

The Origin Areas of Thirteen Markets or Origin Points

\begin{tabular}{ll}
\hline \multicolumn{1}{c}{$\begin{array}{c}\text { Market/ } \\
\text { Origin Point }\end{array}$} & \multicolumn{1}{c}{ Origin Areas (states assigned) } \\
\hline Atlanta, GA & Georgia \\
Birmingham, AL & Alabama \\
Chicago, IL & Illinois, Indiana \\
Cleveland, OH & Ohio, Indiana, Kentucky \\
Columbia, SC & North Carolina, South Carolina \\
Dallas, TX & Texas, Oklahoma, Arkansas \\
Detroit, MI & Michigan, Minnesota, Wisconsin, North Dakota, \\
& South Dakota \\
Los Angeles, CA & California, Arizona, Nevada, Oregon, \\
& Idaho, Washington \\
Louisville, KY & Kentucky, Indiana, Tennessee \\
Miami, FL & Florida \\
New Orleans, LA & Louisiana, Mississippi \\
New York, NY & New York, Maryland, Delaware, Virginia, \\
& Connecticut, Rhode Island, New Hampshire, \\
& Vermont, Massachusetts, Pennsylvania, \\
St. Louis, MO & New Jersey, Ohio, West Virginia \\
& Missouri, Arkansas, Illinois, Kansas, \\
\hline
\end{tabular}

Note: Unloads originating in states not included in this table were deleted from the spatial analysis. 
TABLE 5

Land Constraint Coefficients and Source Information by Crop for South Georgia

\begin{tabular}{|c|c|c|c|c|}
\hline Crops & Yield $^{\mathrm{a}}$ & $\begin{array}{c}\text { Land }^{\mathrm{b}} \\
\text { Constraint } \\
\text { Coefficient }\end{array}$ & $\begin{array}{l}\text { Unload/c } \\
\text { Production } \\
\text { Ratio }\end{array}$ & Adjusted $^{\mathrm{d}}$ \\
\hline & $\begin{array}{c}(100 \mathrm{cwt} / \\
\text { acre })\end{array}$ & $\begin{array}{c}\text { (Acre } / 100 \\
\text { cwt) }\end{array}$ & & $\begin{array}{c}\text { (Acre } / 100 \\
\text { cwt) }\end{array}$ \\
\hline \multicolumn{5}{|l|}{ Produce Crops } \\
\hline Watermelons & 1.00 & 1.00 & 0.4090 & 2.44 \\
\hline Tomatoes & 0.65 & 1.53 & 0.3953 & 3.87 \\
\hline Green Peppers & 0.94 & 1.06 & 0.6804 & 1.56 \\
\hline Cucumbers & 1.03 & 0.97 & 0.1881 & 5.16 \\
\hline Sweet Corn & 1.06 & 0.95 & 0.2139 & 4.42 \\
\hline \multicolumn{5}{|l|}{ Row Crops } \\
\hline Field Corn & 0.31 & 3.25 & - & 3.25 \\
\hline Peanuts & 0.33 & 3.03 & - & 3.03 \\
\hline Soybean & 0.15 & 6.68 & - & 6.68 \\
\hline
\end{tabular}

aYields for Produce crops were obtained from data reported in Agricultural Statistics, and yields for row crops were extracted from Georgia Agricultural Facts.

bLand constraint coefficients are the reciprocals of respective yields.

'Unload/Production ratios represent the total unload quantities shipped, originating in Georgia, divided by total quantities produced in Georgia in June, 1975.

¿Land constraint coefficients were adjusted by dividing the land constraint coefficients by respective unload/ production ratios.

\section{Costs}

Transportation costs are presented in functional form and involve produce commodities only, as interregional competition of row crops is not within the scope of this study. Table 6 shows the transportation cost relationships employed in the model by selected commodity. Transportation cost per hundred cwt is a function of distance (miles) from city to city where each city is the focal point for a given region of origin and/or destination. Unpublished transportation cost functions for fresh tomatoes and cucumbers in the period of interest were available from the USDA. However, such was not the case for green peppers, sweet corn, and watermelons. Transportation cost functions for these commodities were estimated using data provided by the USDA.

Production costs, including total variable and risk costs, are presented in Table 7. The method used to capture risk is quite similar to that of Adams, et al. The risk cost for each crop is the product of variable cost and associated coefficient of variation (risk coefficient). Price variability was used for estimating risk coefficients of fresh produce items while yield variability was used for row crops. Adams, et al. used only yield variability to estimate risk coefficients. However, other approaches have been used, e.g. variability of gross returns, encompassing price and yield variability (Hazell and Scandizzo, Simmons and Pomerada). We used price variability 
TABLE 6

Cost Functions for Transportation Cost per Hundred Hundred Weight for Selected Commodities

\begin{tabular}{lrrc}
\hline \multicolumn{1}{c}{ Commodity } & Intercept & Slope & $\mathbf{R}^{2}$ \\
\hline Tomatoes & 100.000 & 0.293 & $\mathrm{a}$ \\
Cucumbers & 132.000 & 0.140 & $\mathrm{a}$ \\
Green Peppers & 96.550 & 0.261 & 0.65 \\
& $(4.67)$ & $(10.43)$ & \\
Sweet Corn & 178.000 & 0.073 & 0.98 \\
& $(11.12)$ & $(9.25)$ & 0.99 \\
Watermelons, & 116.290 & 0.160 & \\
& $(114.01)$ & $(160.00)$ & \\
\hline
\end{tabular}

${ }^{a}$ Equations for tomatoes and cucumbers were furnished by the USDA.

Note: $t$ values are given in parentheses below respective coefficients. Transportation costs are for shipment by truck.

for produce commodities since yield data for some of the fresh items were not reliable.

TABLE 7

Production Costs of Selected Fresh Produce and Row Crops in South Georgia

\begin{tabular}{|c|c|c|c|c|}
\hline Crops & $\begin{array}{c}\text { Total Variable } \\
\text { Cost }\end{array}$ & $\begin{array}{c}\text { Risk }^{\mathrm{b}} \\
\text { Coefficient }\end{array}$ & $\begin{array}{l}\text { Risk }^{c} \\
\text { Cost }\end{array}$ & $\begin{array}{l}\text { Production }^{\mathrm{d}} \\
\text { Cost } \\
\text { Component }\end{array}$ \\
\hline & $(\$ / 100 \mathrm{cwt})$ & (pct.) & $(\$ / 100 \mathrm{cwt})$ & $(\$ / 100 \mathrm{cwt})$ \\
\hline \multicolumn{5}{|l|}{ Produce Crops } \\
\hline Watermelons & 305.00 & 33.99 & 103.66 & 408.66 \\
\hline Tomatoes & $1,922.60$ & 36.41 & 700.06 & $2,622.67$ \\
\hline Green Peppers & 962.77 & 32.73 & 315.13 & $1,277.91$ \\
\hline Cucumbers & 764.07 & 31.70 & 242.91 & $1,006.99$ \\
\hline Sweet Corn & 535.35 & 26.55 & 142.15 & 677.50 \\
\hline \multicolumn{5}{|l|}{ Row Crops } \\
\hline Field Corn & 344.43 & 23.54 & 81.08 & 425.51 \\
\hline Peanuts & 899.09 & 25.07 & 225.40 & $1,124.49$ \\
\hline Soybeans & 561.35 & 16.90 & 94.87 & 656.21 \\
\hline
\end{tabular}

aSource: Enterprise Budgets, Georgia Cooperative Extension Service, 1977.

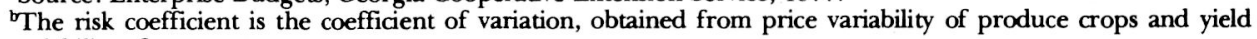
variability of row crops.

'Risk Cost $=$ Total Variable Costs x Risk Coefficient.

dProduction Cost Component $=$ Total Variable Cost + Risk Cost. 


\section{BASE SOLUTION}

The model was used to track as closely as possible, actual cropping patterns in South Georgia and shipping patterns from region to region in the base period, June 1975.

As a starting point, production costs for South Georgia for each produce commodity were added to the transportation costs associated with respective commodities for all regions. Following a solution of the model, costs were adjusted by the dual values of shipments and price differences from region to region to allow the model to track actual patterns and flows of the base period.

In this manner the base model tracked reality closely in all markets except Atlanta. In actuality the Atlanta market received large quantities of fresh produce mostly from Florida. However, our tracking method would not capture shipments from both origins, Georgia and Florida, for the Atlanta market. Thus, as it seemed logical to provide the Atlanta market with produce from its own origin, the base solution does not include shipments from Florida to Atlanta. The same situation also applies to shipments of tomatoes from South Carolina to Atlanta. Thus, supplies from Florida and South Carolina were reduced by the amount actually shipped to Atlanta to prevent these supplies from being allocated elsewhere.

\section{FRESH PRODUCE SHIPPING PATTERN AND PRICE CHANGES}

The effects of increased transportation cost on regional prices, quantities, and shipping patterns of selected fresh vegetables and fruits for 13 markets were evaluated by comparing the base solution with a solution incorporating a 100 percent increase in energy transportation cost relative to the base period. Since the energy expenditure is estimated as 24 percent of the transportation cost of hauling fresh vegetables and fruits in refrigerated trucks (Boles), a 24 percent increase in transportation cost over the base model was actually employed.

Table 8 presents the results of this analysis. Comparison of the adjusted model with the base model reveals significant changes in total consumption, price, and shipping patterns of selected fresh vegetables and fruits. The most significant increases in total quantities consumed occurred in the Miami market. And the most noticeable price adjustment was an 8.70 percent decrease for watermelons in the Miami market. Quantities of watermelons, tomatoes, green peppers, cucumbers, and sweet corn consumed in the Miami market, originating in Florida, increased 5393.35, $88.66,49.09,153.35$, and 67.93 hundred cwt, respectively. The corresponding percentage increases were $2374.25,34.66,70.53,183.17$, and 32.88 , respectively.

Increases in total consumption in other southeastern production areas, Georgia, South Carolina, Texas, and Louisiana, were not as large as that for Florida. With a 100 percent increase in energy cost, the total consumption of watermelons, tomatoes, green peppers, cucumbers, and sweet corn 
TABLE 8

Model Solution of a 100 Percent Increase of Energy Cost (Diesel Fuel), Watermelons,

Tomatoes, Green Peppers, Cucumbers, and Sweet Corn

\begin{tabular}{|c|c|c|c|c|c|c|}
\hline \multirow[b]{2}{*}{ Destinations } & \multicolumn{2}{|c|}{ Watermelons } & \multicolumn{2}{|c|}{ Tomatoes } & \multicolumn{2}{|c|}{ Green Peppers } \\
\hline & Quantity & Diff. & Quantity & Diff. & Quantity & Diff. \\
\hline & $(100 \mathrm{cwt})$ & (pct) & (100 cwt) & (pct) & $(100 \mathrm{cwt})$ & (pct) \\
\hline Atlanta & $345.64^{\mathrm{a}}$ & 0.91 & $332.43^{\mathrm{a}}$ & 0.04 & $27.08^{\mathrm{a}}$ & 0.07 \\
\hline Total consumption & 345.64 & 0.91 & 332.43 & 0.04 & 27.08 & 0.07 \\
\hline Price $(\$ / 100 \mathrm{cwt})$ & $\$ 614.59$ & 0.00 & $\$ 4,152.79$ & 0.00 & $\$ 2,928.62$ & 0.00 \\
\hline Birmingham & $1,422.13^{j}$ & 111.41 & $136.90^{\mathrm{b}}$ & 42.90 & $\begin{array}{c}5.12^{\mathrm{b}} \\
0.00^{\mathrm{j}}\end{array}$ & $\begin{array}{r}\mathrm{NA} \\
-100.00\end{array}$ \\
\hline Total consumption & $1,422.13$ & 111.41 & 136.90 & 42.90 & 5.12 & -69.36 \\
\hline Price $(\$ / 100 \mathrm{cwt})$ & $\$ 554.90$ & -1.63 & $\$ 4,185.75$ & -0.49 & $\$ 2,860.08$ & 0.46 \\
\hline Chicago & $\begin{array}{r}0.00^{\mathrm{f}} \\
1,589.44^{\mathrm{j}}\end{array}$ & $\begin{array}{r}-100.00 \\
47.62\end{array}$ & $\begin{array}{r}12.00^{\mathrm{c}} \\
4.00^{\mathrm{g}} \\
332.45^{\mathrm{j}}\end{array}$ & $\begin{array}{r}0.00 \\
\mathrm{NA} \\
-31.00\end{array}$ & $136.48^{\mathrm{k}}$ & -16.08 \\
\hline Total consumption & $1,589.44$ & -5.80 & 348.45 & -29.43 & 136.48 & -16.08 \\
\hline Price $(\$ / 100 \mathrm{cwt})$ & $\$ 964.08$ & 1.35 & $\$ 4,538.43$ & 1.64 & $\$ 3,364.11$ & 0.88 \\
\hline Cleveland & $5.66^{\mathrm{j}}$ & -99.69 & $\begin{array}{r}336.00^{\mathrm{d}} \\
0.00^{\mathrm{e}} \\
10.87^{\mathrm{j}}\end{array}$ & $\begin{array}{r}0.00 \\
-100.00 \\
-95.02\end{array}$ & $99.95^{\mathbf{j}}$ & -46.62 \\
\hline Total consumption & 5.66 & -99.69 & 346.87 & -47.72 & 99.95 & -46.62 \\
\hline Price $(\$ / 100 \mathrm{cwt})$ & $\$ 770.66$ & 1.38 & $\$ 4,009.86$ & 1.75 & $\$ 3,210.46$ & 1.59 \\
\hline Columbia & $3,003.44^{j}$ & 59.48 & $884.01^{\mathrm{e}}$ & 0.02 & $51.32^{\mathrm{e}}$ & 29.14 \\
\hline Total consumption & $3,003.44$ & 59.48 & 884.01 & 0.02 & 51.32 & 29.14 \\
\hline Price $(\$ / 100 \mathrm{cwt})$ & $\$ 519.62$ & -2.58 & $\$ 3,871.89$ & 0.00 & $\$ 2,897.82$ & -0.45 \\
\hline Dallas & $4,027.50^{\mathrm{f}}$ & 291.48 & $187.44^{\mathrm{f}}$ & 17.19 & $\begin{array}{r}0.00^{\mathrm{b}} \\
122.38^{\mathrm{f}} \\
0.00^{\mathrm{m}}\end{array}$ & $\begin{array}{r}-100.00 \\
127.35 \\
-100.00\end{array}$ \\
\hline Total consumption & $4,027.50$ & 291.48 & 187.44 & 17.19 & 122.38 & 94.90 \\
\hline Price $(\$ / 100 \mathrm{cwt})$ & $\$ 566.26$ & -6.11 & $\$ 4,120.86$ & -1.17 & $\$ 3,293.33$ & -1.99 \\
\hline Detroit & $0.00^{\mathrm{j}}$ & -100.00 & $\begin{array}{l}0.00^{\mathrm{g}} \\
0.00^{\mathrm{h}}\end{array}$ & $\begin{array}{l}-100.00 \\
-100.00\end{array}$ & $128.93^{\mathrm{k}}$ & -17.20 \\
\hline
\end{tabular}


Total consumption Price ( $\$ / 100 \mathrm{cwt})$

Los Angeles

Total consumption

629.00

$-71.55$

Price $(\$ / 100 \mathrm{cwt})$

Louisville

Total consumption

Price ( $\$ / 100 \mathrm{cwt}$ )

\section{Miami}

Total consumption

Price $(\$ / 100 \mathrm{cwt})$

New Orleans

$\$ 884.76$

2.25

$142.46^{j}$

$-50.97$

142.46

$\$ 671.64$

$-50.97$

$5,620.51^{\mathrm{j}}$

$5,620.51$

$\$ 696.33$

$0.00^{\mathrm{b}}$

$1,051.67^{\mathrm{j}}$

$22.50^{\mathrm{k}}$

Total consumption

Price $(\$ / 100 \mathrm{cwt})$

New York

$\$ 665.05$

$0.00^{\mathrm{a}}$

$0.00^{\mathrm{e}}$

$2,766.20^{\mathrm{j}}$

0.27

$2,374.25$

$2,374.25$

$-8.70$

$-100.00$

109.53

0.00

68.65

$-0.80$

$-100.00$

$-100.00$

$-60.54$

Total consumption

St. Louis

$2,766.20$
$\$ 816.30$

$0.00^{\mathrm{f}}$

$-65.62$

1.51

$-100.00$

0.00

Total consumption

$\$ 836.84$

$-100.00$

0.53

922.89

$\$ 4,241.95$

$46.00^{\mathrm{i}}$

$17.36^{\prime}$

63.36

$\$ 3,771.09$

$344.47^{j}$

344.47

$\$ 4,354.12$

$0.00^{\mathrm{e}}$

$124.00^{\mathrm{k}}$

124.00

$\$ 4,162.32$

$43.10^{\mathrm{b}}$

$509.88^{\mathrm{e}}$

$0.00^{\mathrm{f}}$

$469.11^{\mathrm{h}}$

$786.85^{\mathrm{j}}$

$368.00^{1}$

$2,176.93$

$\$ 4,386.98$

$0.00^{\mathrm{f}}$

$138.00^{\mathrm{m}}$

138.00

$\$ 4,552.76$
47.00

$-3.39$

0.00

$-85.75$

$-62.24$

1.42

34.66

34.66

$-1.02$

$-100.00$

0.00

$-8.70$

0.14

$-48.81$

$-70.68$

$-100.00$

$-2.36$

81.21

0.00

$-32.53$

1.67

$-100.00$

0.00

$-27.96$

0.25
128.93

$\$ 3,496.18$

$97.04^{\mathrm{f}}$

$189.44^{\mathrm{h}}$

$0.00^{\mathrm{k}}$

286.48

$\$ 4,204.94$

$5.12^{\mathrm{i}}$

$0.00^{\mathrm{j}}$

5.12

$\$ 3,062.96$

$111.44^{j}$

111.44

$\$ 3,128.10$

$90.06^{\mathrm{k}}$

90.96

$\$ 3,040.78$

$0.00^{\mathrm{a}}$

$189.90^{\mathrm{e}}$

$72.54^{\mathrm{f}}$

$830.53^{\mathrm{j}}$

$53.23^{\mathrm{k}}$

$7.68^{1}$

$1,153.89$

$\$ 2,956.64$

$72.84^{\mathrm{f}}$

$0.00^{\mathrm{j}}$

$3.84^{\mathrm{m}}$

76.68

$\$ 3,400.26$

NOTE: Difference $=($ New model Solution - Base Solution $) /$ Base Solution. Superscripts from a to $\mathrm{m}$ indicated after a specific quantity represent the specific origin of each shipment. They are as follows: a) Atlanta, b) Birmingham, c) Chicago, d) Cleveland, e) Columbia, f) Dallas, g) Detroit, h) Los Angeles, i) Louisville, j) Miami, k) New Orleans, l) New York, and m) St. Louis. NA indicates that the new shipment does not exist in the actual market conditions. 
TABLE 8 (Continued)

\begin{tabular}{|c|c|c|c|c|}
\hline \multirow[b]{2}{*}{ Destinations } & \multicolumn{2}{|c|}{ Cucumbers } & \multicolumn{2}{|c|}{ Sweet Corn } \\
\hline & Quantity & Diff. & Quantity & Diff. \\
\hline & $(100 \mathrm{cwt})$ & (pct) & (100 cwt) & (pct) \\
\hline Atlanta & $54.60^{\mathrm{a}}$ & 0.74 & $136.11^{\mathrm{a}}$ & 0.19 \\
\hline Total consumption & 54.60 & 0.74 & 136.11 & 0.19 \\
\hline Price $(\$ / 100 \mathrm{cwt})$ & $\$ 1,891.80$ & 0.00 & $\$ 1,417.14$ & 0.00 \\
\hline Birmingham & $30.80^{\mathrm{b}}$ & 0.00 & $\begin{array}{r}105.27^{\mathrm{b}} \\
0.00^{\mathrm{j}}\end{array}$ & $\begin{array}{c}\text { NA } \\
-100.00\end{array}$ \\
\hline Total consumption & 30.80 & 0.00 & 105.27 & -19.25 \\
\hline Price $(\$ / 100$ cwt $)$ & $\$ 1,864.79$ & 0.00 & $\$ 1,433.02$ & 0.47 \\
\hline Chicago & $\begin{array}{r}13.47^{\mathrm{c}} \\
0.00^{\mathrm{h}} \\
7.28^{\mathrm{i}} \\
165.23^{\mathrm{j}} \\
18.52^{\mathrm{k}} \\
0.00^{\mathrm{m}}\end{array}$ & $\begin{array}{c}0.00 \\
-100.00 \\
\text { NA } \\
-44.78 \\
-80.96 \\
-100.00\end{array}$ & $\begin{array}{l}5.44^{\mathrm{c}} \\
0.00^{\mathrm{j}}\end{array}$ & $\begin{array}{c}\text { NA } \\
-100.00\end{array}$ \\
\hline Total consumption & 204.51 & -54.50 & 5.44 & -98.89 \\
\hline Price $(\$ / 100$ cwt $)$ & $\$ 2,052.18$ & 2.32 & $\$ 1,405.77$ & 2.04 \\
\hline Cleveland & $\begin{array}{r}36.57^{\mathrm{d}} \\
304.33^{\mathrm{e}}\end{array}$ & $\begin{array}{r}0.00 \\
-16.30\end{array}$ & $\begin{array}{r}1.81^{\mathrm{d}} \\
75.89^{\mathrm{j}}\end{array}$ & $\begin{array}{r}0.00 \\
-83.45\end{array}$ \\
\hline Total consumption & 340.90 & -14.81 & 77.70 & -83.12 \\
\hline Price $(\$ / 100 \mathrm{cwt})$ & $\$ 1,951.77$ & 2.74 & $\$ 1,536.83$ & 3.19 \\
\hline Columbia & $200.21^{\mathrm{e}}$ & 0.50 & $\begin{array}{r}152.46^{\mathrm{e}} \\
0.00^{\mathrm{j}}\end{array}$ & $\begin{array}{c}\text { NA } \\
-100.00\end{array}$ \\
\hline Total consumption & 200.21 & 0.50 & 152.46 & -15.85 \\
\hline Price $(\$ / 100 \mathrm{cwt})$ & $\$ 1,509.37$ & -0.01 & $\$ 1,414.53$ & 0.54 \\
\hline Dallas & $186.73^{\mathrm{f}}$ & 88.41 & $\begin{array}{l}79.86^{\mathrm{f}} \\
92.48^{\mathrm{j}}\end{array}$ & $\begin{array}{c}\text { NA } \\
-53.67\end{array}$ \\
\hline Total consumption & 186.73 & 88.41 & 172.34 & -13.66 \\
\hline Price $(\$ / 100 \mathrm{cwt})$ & $\$ 1,930.84$ & -0.85 & $\$ 1,496.02$ & 3.32 \\
\hline Detroit & $0.00^{\mathrm{e}}$ & -100.00 & $\begin{array}{c}0.00^{\mathrm{b}} \\
59.01^{\mathrm{j}} \\
0.00^{\mathrm{m}}\end{array}$ & $\begin{array}{r}-100.00 \\
-79.50 \\
-100.00\end{array}$ \\
\hline
\end{tabular}


Total consumption

Price (\$/100 cwt)

Los Angeles

Total consumption

Price $(\$ / 100 \mathrm{cwt})$

Louisville

Total consumption Price $(\$ / 100 \mathrm{cwt}$ )

\section{Miami}

Total consumption Price $(\$ / 100 \mathrm{cwt})$

New Orleans

Total consumption Price $(\$ / 100 \mathrm{cwt})$

New York

Total consumption Price (\$/100 cwt)

St. Louis

Total consumption

Price $(\$ / 100 \mathrm{cwt}$ )
0.00
$\$ 2,018.03$

$635.25^{\mathrm{h}}$

635.25

$\$ 1,357.90$

$0.00^{\mathrm{e}}$

$6.20^{\mathrm{i}}$

6.20

$\$ 1,938.12$

$0.00^{\mathrm{e}}$

$237.07^{j}$

237.07

$\$ 1,956.64$

$147.03^{\mathrm{k}}$

147.03

$\$ 1,828.37$

$0.00^{\mathrm{a}}$

$0.00^{\mathrm{e}}$

625.65

$292.60^{1}$

918.25

$\$ 1,942.22$

$0.00^{\mathrm{f}}$

$0.00^{\mathrm{j}}$

$19.25^{\mathrm{m}}$

19.25

$\$ 2,031.56$
$-100.00$

1.39

0.16

0.16

$-0.01$

$-100.00$

$-54.01$

$-81.59$

0.27

$-100.00$

NA

183.17

$-1.47$

115.33

115.33

$-0.81$

$-100.00$

$-100.00$

$-4.19$

0.00

$-60.15$

2.43

$-100.00$

$-100.00$

NA

$-88.21$

0.61
59.01

$\$ 1,580.21$

$943.80^{\mathrm{h}}$

$0.00^{\mathrm{j}}$

943.80

$\$ 1,437.93$

$108.60^{\mathrm{j}}$

108.60

$\$ 1,536.90$

$274.52^{\mathrm{j}}$

274.52

$\$ 1,333.78$

$11.70^{\mathrm{j}}$

$21.78^{\mathrm{k}}$

33.48

$\$ 1,458.50$

$0.00^{\mathrm{e}}$

$1,702.30^{\mathrm{j}}$

$5.44^{1}$

1,707.74

$\$ 1,394.73$

$0.00^{\mathrm{c}}$

$0.00^{\mathrm{f}}$

$0.00^{\mathrm{j}}$

$78.05^{\mathrm{m}}$

78.05

$\$ 1,339.32$
$-87.48$

0.00

$-100.00$

$-11.84$

2.39

$-11.99$

$-11.99$

2.91

32.88

32.88

$-1.33$

$-92.82$

0.00

$-81.88$

2.83

$-100.00$

$-34.96$

0.00

$-38.46$

3.58

$-100.00$

$-100.00$

$-100.00$

NA

$-83.93$

3.31

NOTE: Difference $=($ New Model Solution - Base Solution $) /$ Base Solution. Superscripts from a to $m$ indicated after a specific quantity represent the specific origin of each shipment. They are as follows: a) Atlanta, b) Birmingham, c) Chicago, d) Cleveland, e) Columbia, f) Dallas, g) Detroit, h) Los Angeles, i) Louisville, j) Miami, k) New Orleans, l)

New York, and m) St. Louis. NA indicates that the new shipment does not exist in the actual market conditions. 
in the Atlanta market, originating in Georgia, was increased by $3.13,0.12$, $0.02,0.40$, and 0.26 hundred cwt, respectively. The percentage increases for these produce items were $0.91,0.04,0.07,0.74,0.19$, respectively.

Table 8 shows many other adjustments concerning quantities shipped and consumed and corresponding price adjustments. In general, Table 8 reflects a contraction of shipments to within and near producing regions. And correspondingly, consumption was shown to be down in markets further away from producing areas and up in markets within and near producing regions.

The region with the largest relative reduction was New York. The quantities consumed of watermelons, tomatoes, green peppers, cucumbers, and sweet corn in the New York market decreased by 5,279.06, $1,049.66,176.38,1,385.99$, and $1,067.37$ hundred cwt, respectively. The percentage decreases of produce items were $65.63,32.53,13.26,60.15$, and 38.46 , respectively.

Contrary to our hypothesis, Georgia decreased shipments of watermelons, green peppers, and cucumbers 100 percent or 769.00, 76.03, and 47.81 hundred cwt, respectively. The model reallocated Florida shipments of each commodity to local and near markets. And, major reductions of shipments also occurred for all five commodities from South Carolina.

\section{Production Changes}

A 100 percent increase in energy cost features a dramatic decline in overall produce production and a small increase in overall row crop

\section{TABLE 9}

Model Solution for Crop Production in Georgia Given a 100 Percent Increase in Energy Cost

\begin{tabular}{lrr}
\hline Commodity & Supply & Diff. $^{\text {a }}$ \\
\hline & $(100 \mathrm{cwt})$ & $(\mathrm{pct})$ \\
Produce Crops & & \\
Watermelons. & 346 & -68.90 \\
Tomatoes & 332 & 0.04 \\
Green Peppers & 27 & -73.73 \\
Cucumbers & 55 & -46.47 \\
Sweet Corn & 136 & 0.19 \\
$\quad$ Subtotal & 896 & -42.19 \\
Row Crops & & \\
Field Corn & 556,876 & 0.11 \\
Peanuts & 172,618 & 0.00 \\
Soybeans & 158,698 & 0.03 \\
$\quad$ Subtotal & 888,192 & 0.07 \\
Total & 889,088 & 0.00 \\
\hline
\end{tabular}

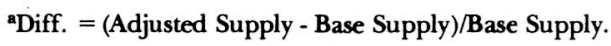


production in South Georgia, Table 9. Reductions for watermelons, green peppers, and cucumbers were substantial. Actual shipments in the base period of tomatoes and sweet corn from Georgia to other regions were small and thus were uncaptured by the base model. Further, the increased transportation cost was not sufficient to affect the production of tomatoes and sweet corn in South Georgia.

\section{CONCLUSIONS}

The findings of this study give some indication of the magnitude of the effects that expected transportation cost increases will have on the spatial distribution of selected fresh produce items. With significantly higher energy costs, allocations of produce to markets adjacent to or within supply areas are expected to increase substantially at the expense of other consuming markets in the nation. However, this expectation perhaps would not be as commanding as indicated by the model solution. Had activity analysis been allowed for all supply regions, other production opportunities might have reduced the increased availability of fresh produce in fixed supply regions of the model.

In view of the trend in rising energy transportation costs, perhaps the most disturbing finding was the overall reduction of supplies of fresh produce and reduced opportunities for Georgia and the Southeast due to a doubling of fuel costs. Results imply that in order to maintain shipments as depicted in the base model, the consumer must be protected through improved income as energy costs rise. Another implication is the importance of more efficient transporting of perishable commodities through, for example, backhauls and rail piggyback service.

The focus of this paper is on the effects of increased transportation cost, due to increasing energy cost, on the interregional flows of selected fresh produce. Thus, the impact of increased production costs on comparative advantage was not addressed.

The model used in this study is based on the simplifying assumptions of pure competition. Thus, it is not a true reflection of reality. Nevertheless, the model does facilitate the determination of the direction of changes and to a lesser extent the magnitude of such changes, given certain rather plausible, circumstances.

\section{FOOTNOTES}

${ }^{1}$ The advantages or disadvantages reflected for Georgia likely would also apply to other southern states that have not been dominant suppliers of fresh produce.

${ }^{2}$ Although according to the evidence watermelon consumption has not increased in recent years, watermelon is an important crop in Georgia as well as other southern states. For this reason, watermelon was included in the analysis.
${ }^{3}$ The quadratic form should be positive semidefinite to ensure that the algorithm reaches a global maximum (Takayama and Judge). This condition is satisfied in that the diagonal elements of $\Sigma$ are positive and the offdiagonal elements are zero.

${ }^{4}$ Washington, DC, is not included. 


\section{REFERENCES}

Adams, R. M, G. A. King, and W. E. Johnston. 1977 "Effects of Energy Cost Increases and Regional Allocation Policies on Agricultural Production." American Journal of Agricultural Economics. 59:444-455.

Babb, J. H. 1977. "An Analysis of the Competitive Situation of the South Carolina Fresh Market Tomato Industry." M.S. Thesis, Clemson University.

Bauer, L. L., G. J. Wells, D. Tholstrup, and J. Epperson. 1979. "The Effect of Increased Transporatation Costs on the Trade Flow of Fresh Peaches." The Review of Regional Studies. 9(3):98-104.

Boles, P. P. 1980. Ouner-Operator Costs of Hauling Fresh Fruits and Vegetables in Refrigerated Trucks. Washington, D. C.: USDA ESCS-82, pp. 5 and 12.

Clevenger, Thomas S., and Frederick Z. Geithman 1977. Market Prospects for New Mexico's Lettuce, Onions, Potatoes, and Sweet Potatoes. New Mexico State University, Agricultural Experiment Station Bulletin 649, Las Cruces.

Georgia Cooperative Extension Service, Farm Management Department. 1977. Crop Enterprise Cost Analysis. Miscellaneous Publication No. 27. 1977. Vegetable Enterprise Cost Analysis. Miscellaneous Publication No. 48.

Georgia Crop Reporting Service. 1977. Georgia Agricultural Facts, 1975-1976.

Georgia Department of Agriculture and USDA, AMS Southern Fruit and Vegetable Report. Various Reports.

Hazell, P.B.R., and P.L. Scandizzo. 1974. "Competitive Demand Structures Under Risk in Agricultural Linear Programming Models." American Journal of Agricultural Economics. 56:235-244.
Mathia, G. A., and J. R. Brooker. 1977. "Relative Profitability of Vine-Ripe Tomatoes in North Carolina and Tennessee." Southern Journal of Agricultural Economics. 9(2):121-127.

Simmons, R. L., and C. Pomarada. 1975. "Equilibrium Quality and Timing of Mexican Vegetable Exports." American Journal of Agricultural Economics. 57:472-479.

Takayama, T., and G. G. Judge. 1971. Spatial and Temporal Price and Allocation Models. Amsterdam: North Holland Publication Company.

Tyner, Wallace E. 1980. "Our Energy Transition: The Next Twenty Years," American Joumal of Agricultural Economics. 62:957-964.

USDA. Agricultural Statistics, 1963 to 1978. Washington, D.C.

USDA, AMS, Annual Market Summaries. Various Reports.

USDA, AMS. Fruit and Vegetable Division, Market News Branch. Fresh Fruit and Vegetable Unload Totals, for 41 Cities. Washington, D.C., FVUS-5, Various Issues.

USDA, ERS. 1980. Food Consumption, Prices and Expenditures. Agricultural Economics Report 138, 1978 Supplement, Washington, D.C.

USDC, Bureau of the Census. 1974 Census of Agriculture. Vol. I, Part 10, Georgia State and County Data, Book 1 Summary Data. Washington, D.C.

- Population Estimates and Projections, Series P-25. Various Reports.

USDC, Bureau of Economic Analysis, Survey of Current Business. Washington, D.C., Various Issues. 